\title{
Passive Voice Transformation
}

\section{Shpresë Qamili, Republic of Kosovo Institution, Albania: Public University " Kadri Zeka"}

*Corresponding Author: (shpresa.qamili@uni-gjilan.net)

Received Date: Feb 29, 2019 Accepted Date: Feb 29, 2019 Published Date: 31-07-2019

Abstract - It is well known that the differences between the languages and the different levels of relationship between them and the use of the English passive voice in Albanian language are complex achievements of hypotheses given by language thinkers, because the language first of all is a process and processes change from time to time as a result of new language achievements and transformations and as a result of changes in people's worldview.

The English and Albanian passive voice do not have a single grammatical structure and that this should be related to numerous legalities that follow the languages in their internal and external development. The studies carried out in terms of linguistic features, even of the passive voice according to the comparative method, have opened new paths to see similarities and differences even in the passive voice structure.

This study is intended to give our modest contribution to notice the similarities and differences in the use of the passive voice as well as its structure in both languages. This contrastive analysis tries to facilitate the acquisition of English as a foreign language for students, pupils, to make the translation from English into Albanian and vice versa easier, to provide linguistic information to language researchers. The comparison is supported by the following English novels and their translated versions in Albanian such as: "Oliver Twist" by Charles Dickens and translated by Skënder Luarasi and "Silas Marner" by George Eliot and translated by Ramazan Hysa, where similar as well as different features have been found.

Keywords: passive voice, active voice, verb, transformation, and object.

\section{Introduction}

When the verb of a sentence is changed from passive voice into the active voice, the other words in the sentence remain unchanged, but there is a change in meaning:

$\mathrm{He}$ is driving to the airport. (active voice)

Ai është duke vozitur për në aeroport.

He is being driven to the airport. (passive voice)

Atë po e vozisin për në aeroport.

The addressed person - the subject of the first sentence is acting actively: the person is driving. The person of the second sentence that refers to the subject is staying passive; someone else is driving. Using the first person singular of the verb classify as an example in the following table we will compare the most used tenses of the passive indicative mood with respective tenses of the active voice:

Table 1. The most used tenses of the passive indicative mood with respective tenses of the active voice:

\begin{tabular}{|l|l|l|}
\hline Tense & Active voice & Passive voice \\
\hline Simple Present & I classify & I am classified \\
\hline
\end{tabular}




\begin{tabular}{|l|l|l|}
\hline Negative Statement & I do not classify & I am not classified \\
\hline Present Continuous & I am classifying & I am being classified \\
\hline Present Perfect & I have classified & I have been classified \\
\hline Simple Past & I classified & I was classified \\
\hline Negative Statement & I did not classify & I was not classified \\
\hline Past Continuons & & \\
\hline Past Perfect & I was classifying & I was being classified \\
\hline Simple Future & I had classified & I had been classified \\
\hline Future Perfect & I will classify & I will be classified \\
\hline Simple, with would & I will have classified & I will have been classified \\
\hline Perfect, with would & I would classify & I would be classified \\
\hline
\end{tabular}

Source: by author

It is characteristic to know that based on the research done so far the most used tenses in English are: Present Perfect, Simple Past \& Past Perfect and modal verbs in combination with some of the verb tenses.

In this paper some of the following aspects will be addressed: transformation of passive voice while preserving the meaning of the sentence; verb transformation from passive to active; transformation of verb which takes the two objects: the direct and indirect object, as well as the use of passive voice.

\section{Transformation of passive voice while keeping the meaning of the sentence}

In order to keep the meaning of the sentence when the voice is changed, it is necessary to change the order of words in the sentence. Changing the verb from active into passive when the verb that receives an object is changed from active into passive in order to keep the meaning of the sentence, the previous object becomes the subject of the verb and the previous subject can be preceded by the preposition 'by' and is placed after the verb. For example:

The wind is rippling the water. (active voice)

Era po e valëzon ujin.

The verb (is rippling) has the subject (wind) and takes the object (water). When the verb is in passive voice and the meaning of the sentence is kept, the previous object (water) becomes the the subject of the verb (sentence) and the subject of the previous sentence (wind) becomes an object with the preposition 'by' (nga), as follows:

The water is being rippled by the wind. (passive voice)

Uji po valëzohet nga era.

Other examples are:

The squirrel ate the nut. (active voice)

Ketri e hëngri lajthinë.

The nut was eaten by the squirrel. (passive voice)

Lajthia u hëngër nga ketri.

It should be noted that when the voice is changed in a sentence that keeps the meaning of the sentence, the verb number must agree with its new subject.

The boys are mowing the lawn. (active voice)

Djemtë janë duke kositur lëndinën.

The lawn is being mowed by the boys. (passive voice)

Lëndina është duke u kositur nga djemtë.

In the first sentence, (boys) is in plural; therefore the plural auxiliary verb is used (are). In the second sentence, the subject (lawn) is in singular; therefore the auxiliary verb (is) is in singular. 


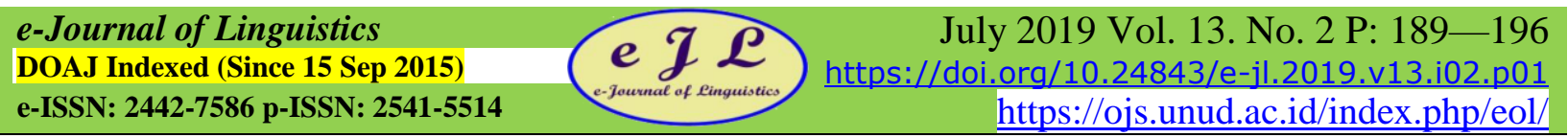

\section{Transformation of verb from passive into active}

If we want to keep the meaning of the sentence, when the verb is changed from passive into active, the subject of the previous sentence becomes the object of the sentence and if the sentence contains a noun phrase beginning with the preposition 'by', the previous object with a preposition becomes the subject of the verb (sentence). For example:

The clover is being eaten by a horse. (passive voice)

Tërfili është duke u ngrënë nga një kalë.

A horse is eating the clover. (active voice)

Një kalë është duke e ngrënë tërfilin.

In the above examples the verb in passive voice is being eaten is changed into is eating in active voice. When we want to keep the meaning of the sentence the clower, the subject of the verb - sentence of passive voice becomes the object of the verb of active voice and is placed after the verb, as well as in the sentence $\boldsymbol{a}$ horse the object with the preposition 'by' becomes the subject of the verb in active voice and is placed before the verb.

\section{Voice transformation of the verb which takes the two objects: the direct and indirect object}

When the verb of the active voice has both objects - the direct and indirect object, then each of them may become the subject of the verb when the verb is changed into passive voice and the meaning is preserved. The object that does not become a subject remains an object. When a passive verb takes an indirect object, the indirect object is usually preceded by a preposition, for example:

\section{The guide will show you the museum. (active voice) \\ Ciceroni do t'ju paraqes muzeun juve. \\ You will be shown the museum by the guide (passive voice) \\ Juve do t'ju paraqitet muzeu nga ciceroni. \\ The museum will be shown to you by the guide. (passive voice) \\ Muzeu do t'ju paraqitet juve nga ciceroni.}

In the first sentence, the active verb 'will show' takes the direct object 'the museum' and the indirect object 'you'. In the second and third sentence, the verb 'will be shown' is in passive voice and the meaning is preserved by changing the word order in the sentence and by using the preposition 'by'. In the second sentence, the previous indirect object 'you' is the subject of the sentence and the previous direct object 'the museum' remains a direct object. In the third sentence, the previous second object 'the museum' is the subject of the sentence and the previous indirect object 'you' is preceded by the preposition 'to'. One such example is:

Your grandmother gave you a present. (active voice)

You were given a present by your grandmother. (passive voice)

A present was given to you by your grandmother. (passive voice)

In the first sentence, the active verb 'gave' takes the direct object 'present' and the indirect object 'you'. In the second and third sentence, the verb 'was given' is in passive voice. In the second sentence, the previous indirect object 'you' is the subject of the verb and the previous object 'present' remains a direct object. In the third sentence, the previous direct object 'the present' is the subject of the sentence and the previous indirect object 'you' is preceded by the preposition 'to'.

\section{The subjunctive mood of passive voice}

All the above passive tenses were in the subjunctive mood. However, the passive verbs can also be conjugated in subjunctive mood. It has been seen that all the tenses in the passive voice are formed by using auxiliary verbs. In the case of subjunctive mood only the first auxiliary verb is in subjunctive mood.

Table 2. The subjunctive mood of the passive verb 'to cure' only in the first person singular 


\begin{tabular}{|l|l|}
\hline Simple Present & I be cured \\
\hline Present Countinuous & I be being cured \\
\hline Present Perfect & I have been cured \\
\hline Present Perfect Continuous & I have been being cured \\
\hline Simple Past & I were cured \\
\hline Past Continuous & I were being cured \\
\hline Past Perfect & I had been cured \\
\hline Past Perfect Continuous & I had been being cured \\
\hline
\end{tabular}

Source: by author

All the other persons of each tense have the same verbal composition as every first person of the above tenses, except the change of persons.

Table 3. Formation of the passive subjunctive tenses

\begin{tabular}{|l|l|l|}
\hline & The auxiliary verb & Verbal form \\
\hline Simple Present & be & Past participle \\
\hline Present Countin. & be being & Past participle \\
\hline Present Perfect & have been & Past participle \\
\hline Present Perf. Cont. & have been being & Past participle \\
\hline Simple Past & were & Past participle \\
\hline Past Continuons & were being & Past participle \\
\hline Past Perfect & had been & Past participle \\
\hline Past Perfect Cont. & had been being & Past participle \\
\hline
\end{tabular}

Source: by author

Like the present tense of the active subjunctive mood, the present tense of passive subjunctive mood is often used in the subordinate clauses beginning with 'that' in sentences containing official orders or requests. As it can be seen from the table above, the simple present of the passive subjunctive mood is formed by the auxiliary verb 'be' followed by the past participle of the verb. The following sentences are examples of the present simple usage of the passive subjunctive mood:

I request that he be invited to speak.

Unë kërkoj që ai ẗ̈ ftohet për të folur.

We asked that our suggestions be considered.

Ne kërkuam që sugjerimet tona të shqyrtohen.

They will insist that their colleague be admitted to the association.

Ata do të insistojnë që kolegu i tyre të pranohet në shoqatë.

\section{The usage of the subjunctive mood past tense forms}

Like the passive subjunctive mood past tense forms, the passive subjunctive mood forms are used in optative and declarative sentences that contain an inaccurate or impossible state, for example:

I wish he were allowed to come.

Unë dëshiroj që ai të jetë lejuar të vij.

It would have been better if they had been invited.

Do të ishte më mirë poqëse ata do të ishin të ftuar.

In the first example, the past simple tense of the passive subjunctive mood 'was allowed' is used to express a desire. In the second example, the past perfect tense of the passive subjunctive mood 'had been invited' is used to express an untrue state. 


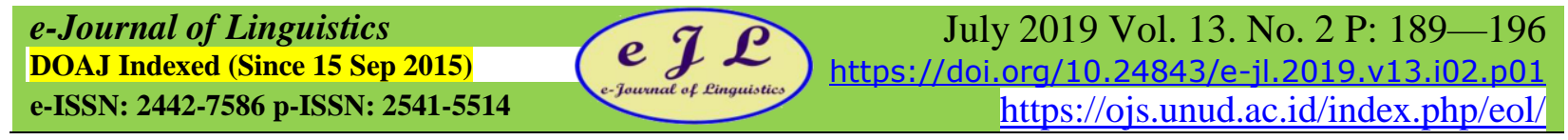

7. Adjectival passives and half-passives (Quirk \& Greenbaum, 2003:168)

In addition to the regular form of the passive voice in the sentence, in the English language a characteristic of the passive voice is also the past participle form, which is derived as an adjective or it is ambiguous. While the first is presented as a verbal passive, the second is presented in the sentence with an intransitive verb consisting of an adjectival passive as subject complement (Huddleston \& Pullum, 2002:1436). They are called half-passives because they contain both verbal and adjectival characteristics. Let's illustrate them with examples:

They were beaten by the policemen. (passive voice)

Ata u rrahën nga policët. (passive voice)

Ata ishin të rrahur nga policët. (verb+adjective)

The verb phrase were beaten can also be understood as ishin të rrahur, so the previous auxiliary verb were can appear as a main verb while beaten as an adjective. Therefore they are called half-passives. In order to know whether it is passive, we must try its opposite, the active voice:

The policemen beat them. (active voice)

Policët i rrahën ata.

The vase was broken. (passive voice)

Vazoja $u$ thye. (passive voice)

Vazoja ishte e thyer. (verb+adjective)

In the first sentence, the word beaten - $u$ rrahën is a verb; in the second sentence, the word broken $-u$ thye, $e$ thyer can appear either as a verb or an adjectve (Huddleston \& Pullum, 2002:1436). The following sentences have features of the active voice as well, for example (Quirk \& Greenbaum, 2003:168):

She broke the vase. (active voice)

Ajo e theu vazon.

You disappointed them. (active voice)

Ju i zhgënjyet ata.

But both sentences have the characteristics of adjectives because they can:

- be intensified (if possible) with: very, too, rather, quite, more etc.

- replace the verb 'be' with linking verbs: feel or seem (Quirk \& Greenbaum, 2003:168).

Let's illustrate the examples with the above sentences:

The vase was quite broken.

They were very disappointed.

If we replace them with the linking verbs (feel - ndiej) and (seem - dukem), the above sentences will appear like this:

The vase seemed broken.

They felt dissappointed.

The distinction between the verbal passives and adjectival passives is that the subject of the verbal passives plays an active role in the sentence, while the adjectival passives indicate the state of the subject.

\section{The passive voice usage}

The passive is later formed in all Indo-European languages as well and was initially used relatively rarely. Its typical function is to enable the construction of the sentence without as agent: they refer to a verbal form which through meaning or something else is clearly characterized as passive.

I. The sentence of the passive voice is sometimes necessary when the speaker wants to hide the agent.

The sentences of the active voice are often more concise than those of passive voice. Expressing the same idea, the passive voice often has up to $30 \%$ to $40 \%$ more words than the active voice:

The fighter punched Ali and dodged the uppercut. (active voice - 8 words)

Boksieri e grushtoi Aliun dhe shmangi goditjen nga poshtë. 


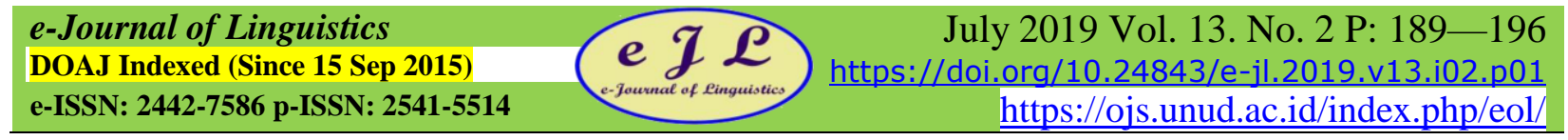

Ali was punched by the fighter and then an uppercut was dodged by him.

(passive voice - 14 words, about $40 \%$ longer)

Aliu u grushtua nga boksieri dhe pastaj goditja nga poshtë u shmang nga ai.

II. The sentences of passive voice have words of pale meaning unlike the sentences of active voice that have the most powerful sense of the sentence, including concrete nouns, "powerful" verbs, and "living" adjectives.

Verbs of active voice may be unclear or confusing especially in long sentences.

My car has been driven to New York.

Vetura ime u vozit për Nju Jork.

(Kush? Folësi? Hajni i veturave? Dikush tjetër?)

Five FBI agents entered the room and the terrorist was plastered against the wall.

Pesë agjentë të FBI hynë në dhomë dhe terroristi u përplas për muri.

Does this mean that five FBI agents plastered the terrorist against the wall? Or does this mean that when the FBI agents entered the room, the terrorist plastered himself against the wall? Or someone else plastered the terrorist before the agents entered the room? With the passive voice structure, it is impossible to clarify the back part of the sentence.

III. However, the author (speaker) often does not know the doer of the action.

A woman was mugged last night in Las Vegas.

Një grua u plaçkit mbrëmë në Las Vegas.

My bag has been stolen.

M'u vodh çanta.

IV. There are several cases when the passive voice is preferable:

In the psychology journals, for psychologist teachers, it is considered that with the passive voice they tend to communicate with feelings and the psychology writings tend to be quite objective. They want the distance created with the passive voice.

When we want to avoid the responsibilities of the action, the passive voice gives us the perfect opportunity to avoid who is responsible.

Ann was given a present.

Anes iu dha një dhuratë.

V. The passive voice is mostly found in government agencies, large companies or elsewhere where the responsible person is unknown.

Mistakes were made.

$\boldsymbol{U}$ bënё gabime.

(Who made the mistakes?)

Writing in the passive voice is often a tedious, unclear, ambiguous, and imprecise thing. But, of course, the passive voice is appropriate under certain circumstances. Using the passive voice is also to avoid the personal pronouns "I" and "we" so that we can leave the direct sentences or the identity of thought.

The passive is used:

- If the subject of the active sentence is not known:

I have been followed.

Unë jam ndjekur

- If the subject of the active sentence is insignificant:

The computer was destroyed.

Kompjutri u dëmtua.

- If we do not want to mention the subject of the active sentence:

This lettuce was grown in our garden.

Kjo marule u rrit në kopshtin tonë.

Jack was fascinated. 


\section{Xheku u magjeps.}

- Because of modesty or diplomacy, the personal pronouns "I" or "we" are not mentioned:

Mistakes were made.

Gabimet u bënё.

- When the agent is excessive to be expressed:

\section{He was examined.}

Ai u shërua.

- When we want to emphasize the outcome of the action without showing the source of information:

Experiment was succesfully done.

Eksperimenti u krye me sukses.

- And even when it is used for specific conversation functions:

George was given an A.

Xhorxhit iu dha një notë A.

Passive is more common in academic prose, news, prose texts submissions, academic writing, scientific culture, and scientific writing. Thus, in the course of direct communication in the spoken language, the long passive is rarely used.

The passive voice is characterized as a marked voice in contrast to the unmarked active voice.

He was accidentally shot yesterday.

Ai u qëllua aksidentalisht dje.

\section{Conclusion}

When dealing with the problem, we have faced many difficulties, because there are no studies and judgments about the underlying issues that would ease our work in achieving better results. Since the passive voice will be seen within the sentence that is a synthetic unit that expresses a certain opinion, then the evaluation and the thought should present not only the idea that expresses the judgment but must express something we affirm and deny. The study area of the problem is infinite and as such requires a profound and continuous study in the future. Occasionally, in the mark of assessments of the necessary problems and phenomena, it has been referred to works and studies of Albanian language experts as well as studies of foreign authors who have been dealing with the treatment and study of the passive voice.

It is thought that there is still work to be done in the most comprehensive study on the passive verb when it is used in a sentence that does not require a direct object since in such cases the verb becomes intransitive. Such verbs cause particular difficulties to be understood fairly and properly, because the actions of the verb remain largely on the subject.

There is no doubt that in the future, there is still to be done about the treatment of the passive voice by the language scholars and linguists. This becomes more current when it is considered that even in the Albanian language, there are no studies on passive voice verbs, reflexive voice verbs, middle and mutual reflexive. For such passive voice verbs, much more analytical studies and research should be done.

\section{References}

Bober, D. Conrad, S. \& Leech, G. (2002). "Student Grammar of Spoken and Written English", Pearson Education, Harlow.

Blaganje, D. \& Konte, I. (1979). “Modern English Grammar" Drzavna Zalozba Slovenije, Ljubljana.

Huddleston, R. \& Pullum, G. (2002). "The Cambridge Grammar of the English Language", Cambridge University Press, Cambridge. 


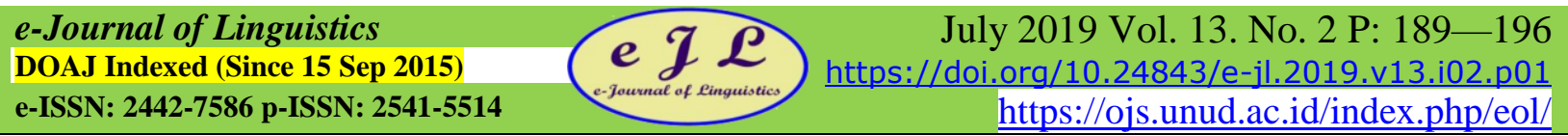

Quirk, R. \& Greenbaum, S. (2003). "A Comprehensive Grammar of the English Language”, Pearson Education, Harlow.

Shibatani, M. (1988). "Passive and Voice", Amsterdam/Philadelphia.

196 